\title{
Temporal alternation between light- and nutrient- limitation of phytoplankton production in a coastal plain estuary
}

\author{
Jonathan R. Pennock ${ }^{1,2, *}$, Jonathan H. Sharp ${ }^{1}$ \\ ${ }^{1}$ University of Delaware, College of Marine Studies, 700 Pilottown Road, Lewes, Delaware 19958, USA \\ ${ }^{2}$ Marine Environmental Sciences Consortium, University of Alabama, 101 Bienville Boulevard, Dauphin Island, Alabama 36528, USA
}

\begin{abstract}
The potential for light-and nutrient-limitation of phytoplankton production was examined in the Delaware Estuary, USA, by combining a hierarchy of experimental approaches including smallscale bioassay experiments, ecosystem-level analysis of nutrient concentration and stoichiometric ratios, and light-limitation modeling. Light was found to be the predominate regulator of phytoplankton growth throughout the estuary during the winter period as a result of high turbidity and a wellmixed water column. However, during late spring, phosphorus (P) was found to limit growth. This observation was confirmed at each of the experimental levels, and was related to several factors, including elevated input ratios ( $\geq 30: 1)$ of dissolved inorganic nitrogen (DIN) to $\mathrm{PO}_{4}$ in river waters, accumulation of $\mathrm{P}$ into phytoplankton, and low rates of $\mathrm{P}$ regeneration. During summer, $\mathrm{P}$ no longer limited production. At this time $\mathrm{DIN}: \mathrm{PO}_{4}$ ratios and bioassay experiments revealed the potential for nitrogen (N) limitation - particularly in the lower estuary - while particulate composition ratios and ecosystem nutrient flux estimates gave contradictory evidence. From these data it appears that $N$ was potentially limiting to phytoplankton biomass but that the constant flux of $\mathrm{N}$ from upstream and rapid $\mathrm{N}$ regeneration maintained non-nutrient-limited steady-state growth. These data document a pattern of recurring system-wide variations in the factors that limit phytoplankton production over several annual sequences. These temporal and spatial variations are related to both light availability - as regulated by incident light, suspended sediment concentration, and depth of the surface mixed-layer and nutrient availability - as determined by riverine inputs and in situ biogeochemical processes.
\end{abstract}

KEY WORDS: Estuary $\cdot$ Phytoplankton · Nutrient-limitation $\cdot$ Light-limitation

\section{INTRODUCTION}

One of the principal goals of phytoplankton ecology has been to understand the factors that regulate phytoplankton production in aquatic ecosystems. The general approach to this question has focused on determining a single factor that limits phytoplankton growth (Liebig 1855) over an experimental hierarchy ranging from small bottles (Ryther \& Dunstan 1971, Smayda 1974, Goldman 1976, Zevenboom et al. 1982, Rudek et al. 1991), to mesocosms (Nixon et al. 1984, D'Elia et al. 1986), to whole ecosystems (Schindler 1975, 1985, Smith 1984). At each of these hierarchical

- Please address reprint requests to J. R. Pennock at the Dauphin Island address levels, a variety of specific indicators have been used to assess nutrient limitation, including, for example, inorganic nutrient stoichiometry and flux (Vollenweider 1976, Nixon \& Pilson 1984), phytoplankton growth (Sakshaug 1977), particulate (plankton) composition ratios (Goldman et al. 1979, Copin-Montegut \& Copin-Montegut 1983), and modeling at both the cellular (Droop 1974, 1977) and ecosystem (Nixon \& Pilson 1983, Smith 1984) levels.

This general approach has been successful for assessing the regulation of phytoplankton growth in freshwater lakes, where there is a general consensus that $\mathrm{P}$ is most often limiting to phytoplankton growth (Schindler 1977). An important feature of this conclusion is that it is corroborated by results of studies from each of the above hierarchial levels (Hecky \& Kilham 
1988), including bioassay experiments (Maestrini et al. 1984, Schelske 1984, Vincent et al. 1984), mesocosms (Healey \& Hendzel 1980), and ecosystem-level N:P loading ratios (Healey \& Hendzel 1980) and particulate composition ratios (Healey 1978).

In oceanic and coastal systems, $\mathrm{N}$ is perceived as the nutrient most likely to limit phytoplankton production. This general premise derives primarily from smallscale bioassay experiments (e.g. Ryther \& Dunstan 1971, Goldman 1976). In contrast to freshwater systems, however, observations over larger time and space scales often offer contradictory evidence. For example, $\mathrm{N}$-limitation has been inferred in coastal waters at the ecosystem level using mass balance arguments (Sharp \& Church 1980), while longer-term ecosystem-level mass balance analysis suggests that $P$ ultimately regulates marine primary production (Broecker \& Peng 1982, Smith 1984). The contradictory results obtained from such studies are often attributed to differences in scale over both time and space.

The influence of scale is particularly evident in the estuarine environment, where the hierarchical approach presented above has been even less successful at identifying a common factor that limits phytoplankton production (Hecky \& Kilham 1988). In general, $\mathrm{N}$ is considered to be the major regulator of estuarine phytoplankton production (Boynton et al. 1982). However, variations from this general pattern are numerous. For example, in turbid systems, light-limitation has been found to be an important regulator of biomass (Wofsy 1983, Pennock 1985), while under non-lightlimiting conditions, each of the major nutrients, nitrogen (Smayda 1974, D'Elia et al. 1986, Dortch \& Whitledge 1992), phosphorus (Meyers \& Iverson 1981, D'Elia et al. 1986, Harrison et al. 1990) and silicate (D'Elia et al. 1983), has been found to limit phytoplankton growth and/or biomass in different estuarine ecosystems. Although such variations are often interpreted as being a function of geographic differences, recent studies (e.g. D'Elia et al. 1986, Rudek et al. 1991, Fisher et al. 1992) have observed temporal variations in the factors limiting production. We believe that such variability is more prevalent than has been previously documented and suggest herein that natural physical and biogeochemical processes provide predictable constraints on the regulation of phytoplankton productivity. Of these processes, those arising from physical flushing and mixing cycles, and biogeochemical rate processes (e.g. phytoplankton growth and biomass accumulation, and both water-column and benthic remineralization) are particularly important in the estuarine environment.

In this study, we examined variations in phytoplankton production in relation to the light and nutrient fields along the longitudinal axis of the Delaware Estuary,
USA, over several seasonal cycles. Seasonal transitions between light-and nutrient-limitation of phytoplankton growth were assessed and confirmed by experiments at various levels of control, including small-scale bioassay experiments, ecosystem-level analysis of nutrient concentration and stoichiometric ratios, light-limitation modeling and determination of plankton organic composition ratios. Finally, we were able to document the observed transition between limiting factors in relation. to variations in the major physical and biogeochemical processes acting in the system.

\section{STUDY AREA AND METHODS}

Study area. The Delaware Estuary is a drowned river-valley extending $240 \mathrm{~km}$ into the mid-Atlantic coastal plain from the bay mouth to the fall line at Trenton, New Jersey (Fig. 1). The upper reach of the river, between Trenton and just south of its confluence with the Schuylkill River at Chester, Pennsylvania (220 to $130 \mathrm{~km}$ from the mouth), is classified as freshtidal and is dominated by the flow of the Delaware and Schuylkill Rivers (Albert \& Krausch 1988). Between Chester and the mouth of the estuary $(130$ to $0 \mathrm{~km})$ estuarine mixing occurs, resulting in salinity ranging from 0 to $30 \%$ (Sharp et al. 1982). In this region, freshwater discharge is still seasonally important but the mean freshwater residence time is sufficiently long $(\sim 100 \mathrm{~d})$ that biogeochemical processes within the lower estuary impart an important influence on the system (Sharp et al. 1986). Although the estuary has a strong anthropogenic influence, the major input of organic matter has been shown to result from in situ phytoplankton production (Cifuentes et al. 1988, Cifuentes 1991). Similarly, both phytoplankton (Pennock 1985, 1987, Pennock \& Sharp 1986) and bacterial processes (Coffin \& Sharp 1987, Lebo 1990) have been shown to influence the overall nutrient cycle.

Samples for this study were collected along the longitudinal axis of the estuary between Trenton and the mouth of the bay in 1985 and 1987. As part of ongoing biogeochemical studies of the estuary begun in 1980, these annual sequences represent times during which particularly intensive temporal and spatial sampling was undertaken. During 9 cruises in 1985 , sampling was focused temporally on the spring phytoplankton bloom and spatially on the salinity gradient between Chester and the bay mouth. At this time, 8 series of nutrient enrichment experiments were completed in addition to standard hydrographic, chemical and phytoplankton analyses. In 1987, 13 cruises were undertaken, with an increased focus on processes in the tidal river in addition to the saline estuary, and coverage over the complete annual cycle. 


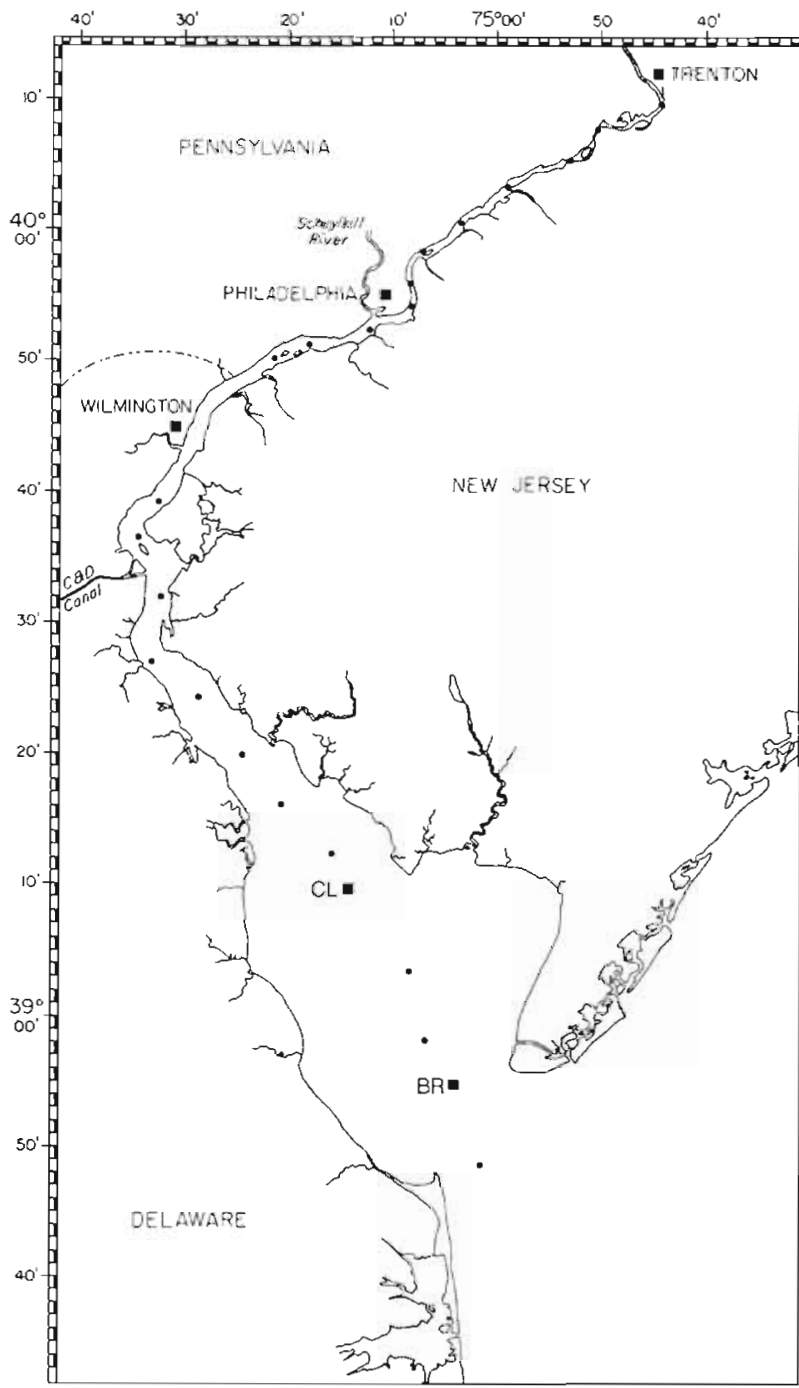

Fig. 1 The Delaware Estuary, USA, depicting the sampling region from the head of tide at Trenton, NJ $(220 \mathrm{~km})$ to the mouth of the estuary $(0 \mathrm{~km})$. Solid dots are the approximate station locations $( \pm 1 \mathrm{~km}$ ). Stations CL and BR in the lower bay are the locations of samples collected for nutrient enrichment experiments in 1985

Chemical and biological sampling. Samples were collected from the RV 'Cape Henlopen' at 1 to $2 \mathrm{~m}$ depth using $10 \mathrm{l}$ Niskin bottles on a rosette sampler configured with a Niel Brown Mark IIIb CTD. Inorganic nutrients were determined colorimetrically using the manual methods of Strickland \& Parsons (1972; $\mathrm{NO}_{2}, \mathrm{NO}_{3}, \mathrm{PO}_{4}$ and $\mathrm{SiO}_{2}$ ) and Butler \& Tibbets (1972) modified for small volumes (Sharp et al. 1982). Particulate organic carbon and nitrogen (PC, PN) were determined via high temperature combustion using a Hewlett-Packard 185B CHN analyzer (Sharp 1974), while particulate organic phosphorus (PP) was analyzed colorimetrically after manual combustion following the method of Solorzano \& Sharp (1980).
Suspended sediment concentration was determined gravimetrically after filtration onto tared $1 \mu \mathrm{m}$ Nuclepore filters and drying at $50^{\circ} \mathrm{C}$ for several days. Chlorophyll a (chl a) was analyzed fluorometrically using a Turner Model 110 Fluorometer calibrated with pure chlorophyll a (Sigma Chemical) to the equations of Lorenzen (1967) (see Strickland \& Parsons 1972).

Phytoplankton production was determined using $24 \mathrm{~h}{ }^{14} \mathrm{C}$ incubations modified from the general procedures of Eppley \& Sharp (1975). Sub-samples were distributed to $65 \mathrm{ml}$ bottles, spiked with 2. $\mu \mathrm{Ci}$ of $\left[{ }^{14} \mathrm{C}\right] \mathrm{HCO}_{3}$, and incubated at 6 light levels $(100,60$ $30,12,3.3$, and $1.1 \%$ of incident PAR, photosynthetically active radiation) obtained with neutral density screens in a deck incubator flushed with surface seawater. After $24 \mathrm{~h}$, incubations were terminated by filtering the particulate matter onto Whatman GF/C filters under reduced $(<350 \mathrm{~mm} \mathrm{Hg}$ ) vacuum, and rinsing with filtered seawater. Wet filters were immediately placed in $7 \mathrm{ml}$ scintillation vials containing Aquasol-2, and subsequently counted on a scintillation counter. Daily areal phytoplankton production (g C $\mathrm{m}^{-2} \mathrm{~d}^{-1}$ ) was estimated at each station by fitting the productivity measured at each of the light levels ( $\mathrm{mg} \mathrm{C}$ $\mathrm{l}^{-1} \mathrm{~d}^{-1}$ ) to a hyperbolic tangent function (Pennock \& Sharp 1986) and integrating these measurements with light availability as described by the diffuse attenuation coefficient, $k$ (see Pennock \& Sharp 1986 for details).

Light-limitation modeling. Light-limitation is a difficult phenomenon to detect in the field, particularly in well-mixed estuarine environments where classic physiological responses to low light conditions are not observed (Harding et al. 1986, Pennock \& Sharp 1986). Previous studies of the Delaware River (Wofsy 1983) and Estuary (Pennock 1985) have demonstrated that light availability is an important regulator of phytoplankton biomass in the system using a steady state 'critical-depth' model (Wofsy 1983). In the present study, light-limitation was assessed using this model, where phytoplankton biomass in the surface mixedlayer is described by the equation:

$$
P=\frac{1}{k_{\mathrm{c}}}\left[\frac{B}{R_{0} Z}-\left(k_{\mathrm{w}}+k_{\mathrm{s}}\right)\right]
$$

where $P\left(\mathrm{mg} \mathrm{Cl}^{-1}\right)$ is the steady-state standing stock of phytoplankton carbon. The specific coefficients used in the model (listed below in parentheses) were derived for the Delaware Estuary during previous studies (Pennock 1985). $R_{0}\left(10 \%\right.$ of $P_{\text {max }}$ maximum photosynthetic capacity) is the respiration due to phytoplankton and heterotrophs in a mixed layer of depth $Z$ (Wofsy 1983). Other coefficients are: attenuation of light in the water column due to water, $k_{w}\left(k_{\mathrm{w}}=0.095 \mathrm{~m}^{-1}\right)$; suspended sediment, $k_{\mathrm{s}}\left[k_{\mathrm{s}}{ }^{\prime}=0.075 \mathrm{~m}^{-1} /\left(\mathrm{mg} \mathrm{l}^{-1}\right)\right]$; and chlorophyll, 
$k_{c}\left[k_{c}{ }^{\prime}=0.020 \mathrm{~m}^{-1} /\left(\mu \mathrm{g} \mathrm{l}^{-1}\right)\right] ;$ where $k$ is the product of the concentration of a particular constituent and its specific attenuation coefficient, $k^{\prime}$ (Pennock 1985). $B$ is a dimensionless parameter describing the ambient light field and the diurnal mean water-column integrated rate of photosynthesis given by:

$$
B=L \mu_{\mathrm{av}}\left[\ln \left(2.7 \frac{I_{0}}{I_{k}}\right)\right]
$$

where $L$ is the sunlit fraction of the day, $\mu_{\mathrm{av}}$ is the average cosine of the solar zenith angle over the sunlit portion of the day, and $I_{k}$ is the light intensity at which photosynthesis is saturating (see Pennock 1985). Carbon biomass calculated using this equation was converted to chlorophyll concentration using a carbon: chlorophyll ratio of $30: 1$.

Theoretically, periods during which model prediction of biomass was greater than observed biomass i.e. model overprediction - are indicative of times when factors other than light - e.g. nutrients or grazing - were regulating phytoplankton growth. For this study, we chose a value of $50 \%$ overprediction as indicative of periods when light was not the primary regulator of phytoplankton biomass. This level was determined through sensitivity analysis, by estimating the uncertainty of several potential variants in the model, including the carbon:chlorophyll ratio (30:1 to $80: 1$; Harris 1986), the analytical precision of suspended sediment and chlorophyll analyses $(-5 \%)$, and the coefficient $R_{0}(10$ to $20 \%)$.

Nutrient-limitation experiments. During 1985, samples were collected for nutrient-limitation experiments at 2 stations during each cruise. These stations were representative of the mid-estuarine region where the annual spring bloom occurs (Stn CL), and the mouth of the estuary (Stn BR) as shown in Fig. 1. At these stations, sub-samples were distributed to $1 \mathrm{l}$ polycarbonate bottles to which $20 \mu \mathrm{Ci}$ of $\left[{ }^{14} \mathrm{C}\right] \mathrm{HO}_{3}$ and a nutrient complement (see below) were added. These samples were then incubated in deck incubators at ambient water temperature and $60 \%$ of ambient light intensity. Daily, over a $4 \mathrm{~d}$ time-series, duplicate $50 \mathrm{ml}$ aliquots were filtered onto Whatman GF/C filters for the determination of ${ }^{14} \mathrm{C}$ incorporation into the particulate fraction.

Nutrient additions were taken from IMR/10 stock solutions (Eppley et al. 1967) that, for full complements, resulted in a final concentration of $50 \mu \mathrm{M}$ nitrogen, $5 \mu \mathrm{M}$ phosphate, $25 \mu \mathrm{M}$ silicate and the IMR/10 complement of trace metals and vitamins. Each experiment included (1) a control, to which no nutrient addition was made, (2) samples to which nutrients were added in the full complement, and (3) samples to which nutrients were added in the full complement minus either nitrogen or phosphorus.
Limitations with incubator space and cruise logistics resulted in these treatments being unreplicated for individual samples and dates; thus, statistical analysis is inappropriate. Within-sample variability of replicate samples never varied by more than $4 \%$. While these bioassay experiments provide only descriptive support of the patterns of nutrient-limitation discussed herein, we believe that the replication of patterns between different cruises carried out during the same season provide important corroborative evidence of nutrient-limitation patterns in the estuary. For each experiment, time-series data displayed one of 3 general treatment effects, that for the purpose of discussion we denote as: (1) 'no difference' where uptake in the nutrient-enriched and control incubations displayed no clear differences through the incubation (e.g. Fig. 11, February); (2) 'stoichiometrically deplete' (SD), where uptake in the control and one of the nutrient treatments decreased as nutrients were exhausted after Day 1, while the full complement and the other nutrient treatment maintained a constant rate through time (e.g. Fig. 10, March for P; Fig. 11, March for $N$ ); and (3) 'nutrient-limited' (NL), where uptake rates in a nutrient-enriched sample were stimulated with respect to the unenriched sample (e.g. Fig. 10, August). Note that the difference between these effects is that the SD treatment is characterized by lowered growth that is caused by the exhaustion of the stoichiometrically deplete nutrient $(\mathrm{P}$ if DIN: $\mathrm{PO}_{4}>16: 1_{i} \mathrm{~N}$ if DIN:PO $<16: 1 ;$ DIN = dissolved inorganic nitrogen) under culture conditions, while the NL treatment is characterized by stimulated growth that results from the addition of one or both of the nutrients.

\section{RESULTS}

\section{Field observations}

Phytoplankton biomass and production

Chlorophyll concentrations displayed recurring seasonal patterns of bloom formation and dissipation in 1985 and 1987 (Fig. 2). The most prominent feature was the winter/spring bloom which began near the mouth of the bay $(\sim 10 \mathrm{~km})$ in February and migrated up the estuary until it dissipated in the mid-estuary $(\sim 100$ to $120 \mathrm{~km})$ in late May. This bloom attained concentrations between 40 and $60 \mu \mathrm{g} \mathrm{chl} \mathrm{a} \mathrm{l^{-1 }}$, and was dominated by the diatom Skeletonoma costatum. During summer, chl a concentrations in the lower estuary $\left(0\right.$ to $50 \mathrm{~km}$ ) were usually 2 to $10 \mu \mathrm{g} \mathrm{l}^{-1}$, except during sporadic blooms of $>10 \mu \mathrm{g} \mathrm{I}^{-1}$ in the region 20 to $50 \mathrm{~km}$ upstream from the mouth. In addition 

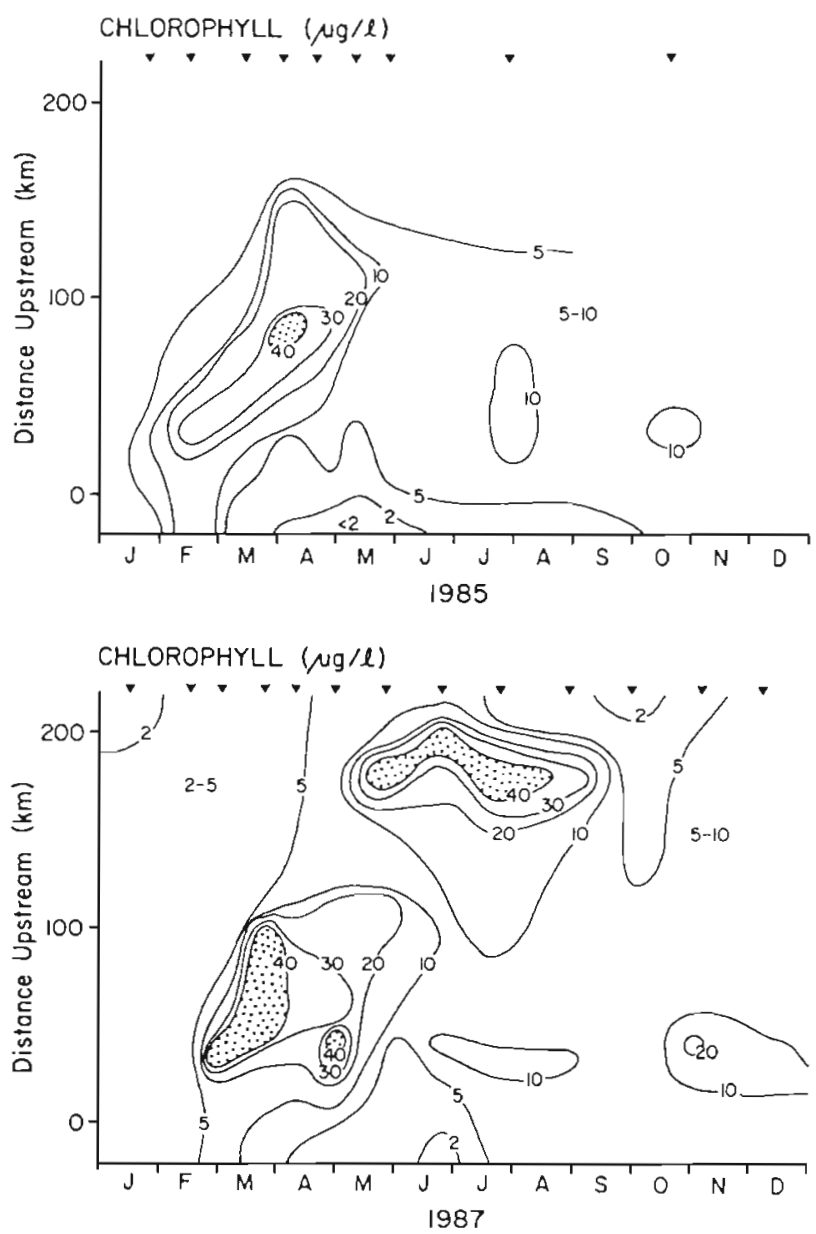

Fig. 2. Chlorophyll a concentration versus distance upstream for full seasonal cycles during 1985 and 1987. The stippled area delineates concentrations $\geq 40 \mu \mathrm{g} \mathrm{l}^{-1}$. The distance axis runs from $0 \mathrm{~km}$ at the mouth of the estuary to $220 \mathrm{~km}$ at Trenton. NJ Triangles along the upper $x$-axis indicate sampling times. Insufficient sampling was done upstream of $130 \mathrm{~km}$ in 1985 to compare the tidal river region in the 2 years

to these lower estuary blooms, chl a concentrations in excess of $40 \mathrm{\mu g} \mathrm{l}^{-1}$ were observed in the river between Trenton and Philadelphia (150 to $210 \mathrm{~km}$ ) during the summer of 1987.

Phytoplankton production also displayed recurring annual sequences (Fig. 3). Between October and March phytoplankton production in the river and upper estuary (upstream of $100 \mathrm{~km}$ ) was always $<0.1 \mathrm{~g}$ $\mathrm{C} \mathrm{m} \mathrm{m}^{-2} \mathrm{~d}^{-1}$. Riverine production reached a maximum of $>3 \mathrm{~g} \mathrm{C} \mathrm{m}^{-2} \mathrm{~d}^{-1}$ during the mid-summer chlorophyll maximum, upstream of the Philadelphia metropolitan area $(150$ to $200 \mathrm{~km}$ ). In the lower estuary, production was $>0.2 \mathrm{~g} \mathrm{C} \mathrm{m}^{-2} \mathrm{~d}^{-1}$ throughout most of the year and attained rates $>2 \mathrm{~g} \mathrm{C} \mathrm{m}^{-2} \mathrm{~d}^{-1}\left(>4 \mathrm{~g} \mathrm{C} \mathrm{m}^{-2} \mathrm{~d}^{-1}\right.$ at particular stations) during the spring bloom and sporadically throughout the summer period. In most cases, production rates varied directly with chlorophyll con-
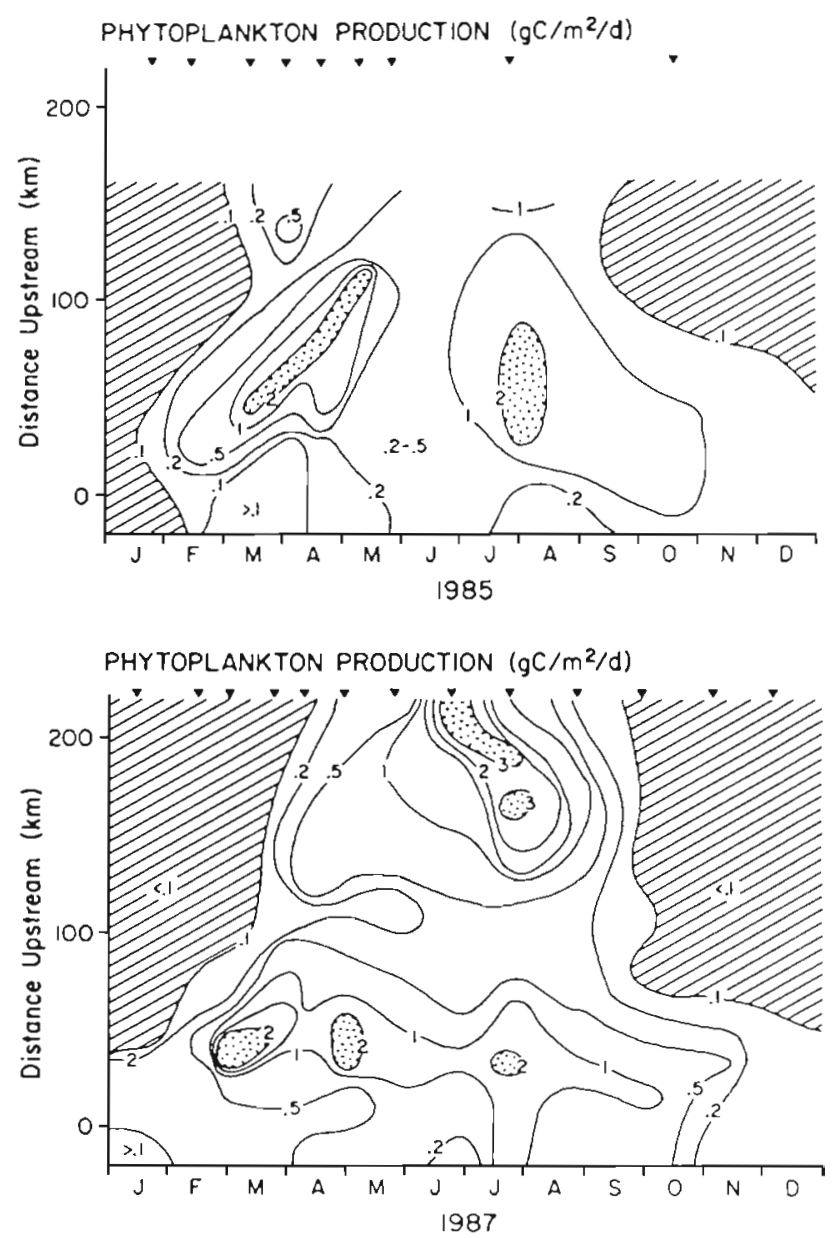

Fig. 3. Phytoplankton production versus distance upstream for full seasonal cycles during 1985 and 1987. The stippled area delineates production rates $\geq 2 \mathrm{~g} \mathrm{C} \mathrm{m}^{-2} \mathrm{~d}^{-1}$ while the hatched area represents rates $\leq 0.1 \mathrm{~g} \mathrm{C} \mathrm{m}^{-2} \mathrm{~d}^{-1}$. The distance axis runs from $0 \mathrm{~km}$ at the mouth of the estuary to $220 \mathrm{~km}$ at Trenton, NJ. Triangles along the upper $x$-axis indicate sampling times. Insufficient sampling was done upstream of $130 \mathrm{~km}$ in 1985 to compare the tidal river region in the 2 years

centration except when the rate of production per unit biomass $\left(P_{\mathrm{m}}^{\mathrm{B}}: \mu \mathrm{g} \mathrm{C} \mu \mathrm{g} \mathrm{chl} \mathrm{a}^{-1} \mathrm{~d}^{-1}\right)$ increased significantly as a result of species composition changes during summer (see Pennock \& Sharp 1986).

\section{Inorganic nutrient distributions}

Previous research has shown that nutrient concentrations in the Delaware Estuary are elevated in the freshwater region and decrease to lower concentrations toward the mouth of the estuary as a result of estuarine mixing (Sharp et al. 1982, 1984) and uptake by phytoplankton (Pennock 1987). This general pattern was maintained over the 1985 and 1987 seasonal cycles, although the more detailed sampling during 
the late spring and summer of these years revealed more extensive patterns of depressed nitrogen and phosphate concentrations than has been reported previously.

DIN concentrations reached a maximum of 100 to $200 \mu \mathrm{M}$ as a result of anthropogenic inputs in the river (130 to $150 \mathrm{~km}_{i}$ Fig. 4). In the river, both $\mathrm{NH}_{4}$ and $\mathrm{NO}_{3}$ were important contributors to the DIN pool (Pennock 1987. Sharp 1988). In the lower estuary, $\mathrm{NO}_{3}$ dominated the DIN pool with concentrations at the bay mouth in excess of $5 \mu \mathrm{M}$ between September and February. Despite typically high DIN concentrations throughout the estuary over most of the year, low concentrations $(<1 \mu \mathrm{M})$ were consistently observed near the mouth of the estuary $(0$ to $20 \mathrm{~km})$ between April and August.
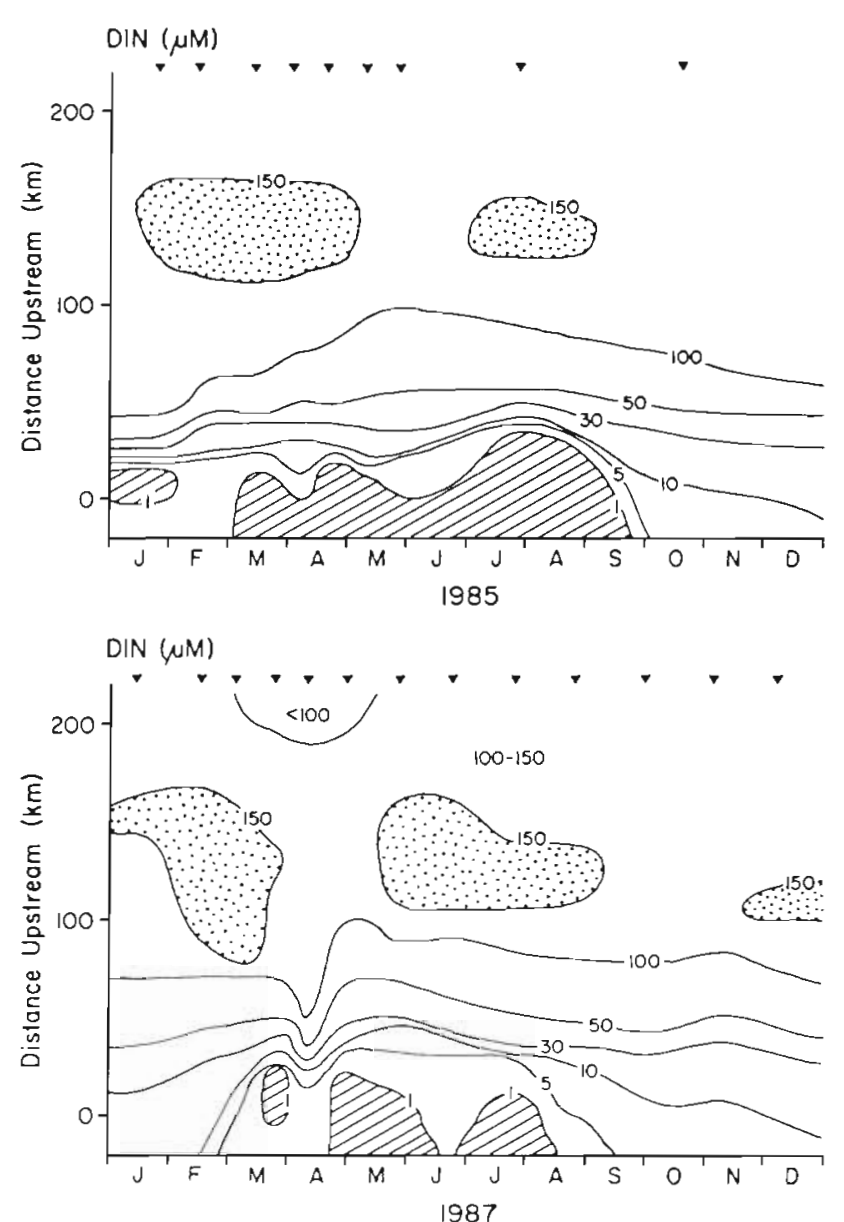

Fig. 4. Dissolved inorganic nitrogen $\left(\mathrm{NH}_{4}, \mathrm{NO}_{2}\right.$ and $\left.\mathrm{NO}_{3}\right)$ concentration (DIN) versus distance upstream for full seasonal cycles during 1985 and 1987. The stippled area delineates DIN concentrations $\geq 150 \mu \mathrm{M}$ while the hatched area represents concentrations $\leq 1 \mu \mathrm{M}$. The distance axis runs from $0 \mathrm{~km}$ at the mouth of the estuary to $220 \mathrm{~km}$ at Trenton, NJ. Triangles along the upper $x$-axis indicate sampling times. Insufficient sampling was done upstream of $130 \mathrm{~km}$ in 1985 to compare the tidal river region in the 2 years
Phosphate concentrations are typically enriched in the river ( 2 to $>4 \mu \mathrm{M}$ ) with decreasing concentrations downstream (Sharp 1988), although riverine concentrations can vary appreciably from year to year in conjunction with differences in river discharge (Lebo \& Sharp 1992) as can be seen with higher concentrations in 1985 and in 1987. During this study, $\mathrm{PO}_{4}$ depletion was particularly pronounced during the spring, with concentrations $<0.1 \mu \mathrm{M}$ observed during March and April in mid-estuary just spatially downstream and temporally after the spring biomass maximum (Fig. 5). During the remainder of the year, $\mathrm{PO}_{4}$ concentrations greater than $0.5 \mu \mathrm{M}$ extended throughout the estuary.
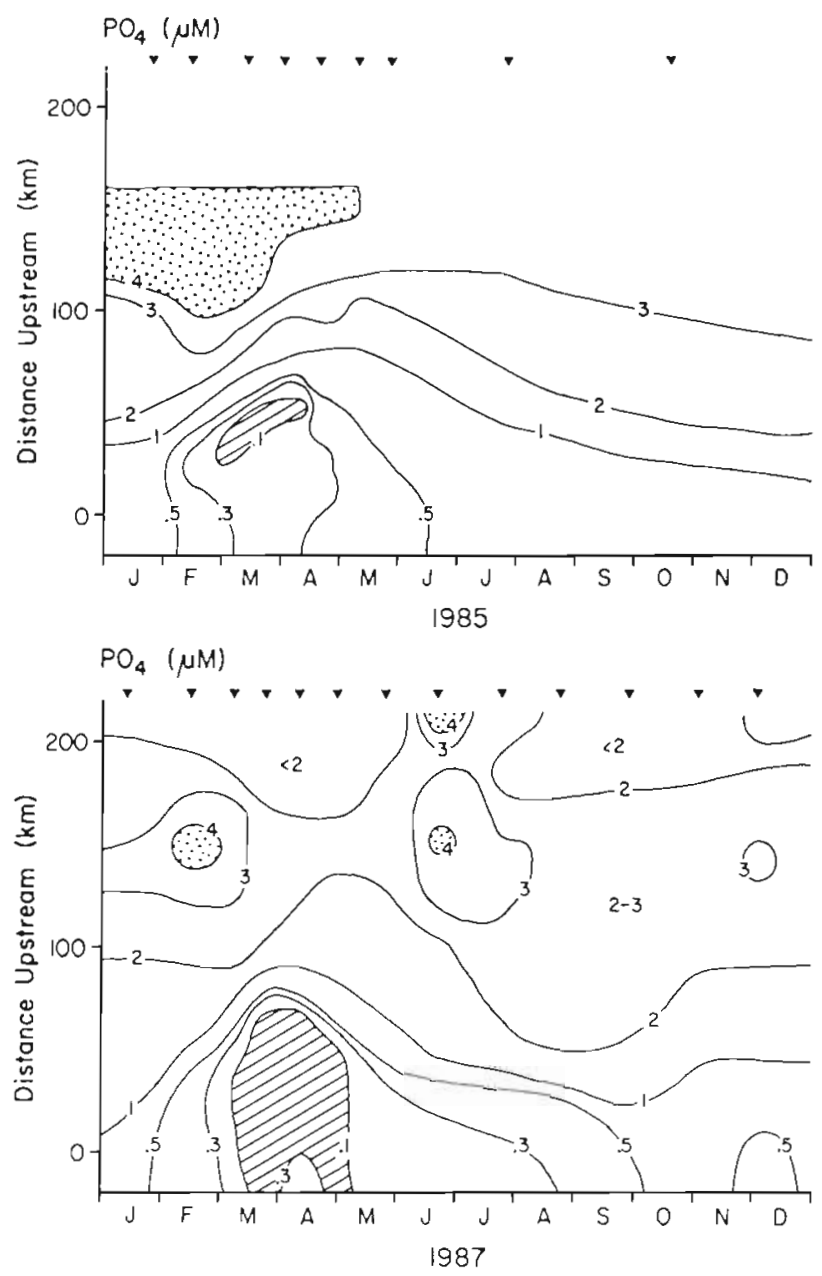

Fig. 5. Phosphate concentration $\left(\mathrm{PO}_{4}\right)$ versus distance upstream for full seasonal cycles during 1985 and 1987 . The stippled area delineates $\mathrm{PO}_{4}$ concentrations $\geq 4 \mu \mathrm{M}$ while the hatched area represents concentrations $\leq 0.1 \mu \mathrm{M}$. The distance axis runs from $0 \mathrm{~km}$ at the mouth of the estuary to $220 \mathrm{~km}$ at Trenton, NJ. Triangles along the upper $x$-axis indicate sampling times. Insufficient sampling was done upstream of $130 \mathrm{~km}$ in 1985 to compare the tidal river region in the 2 years 

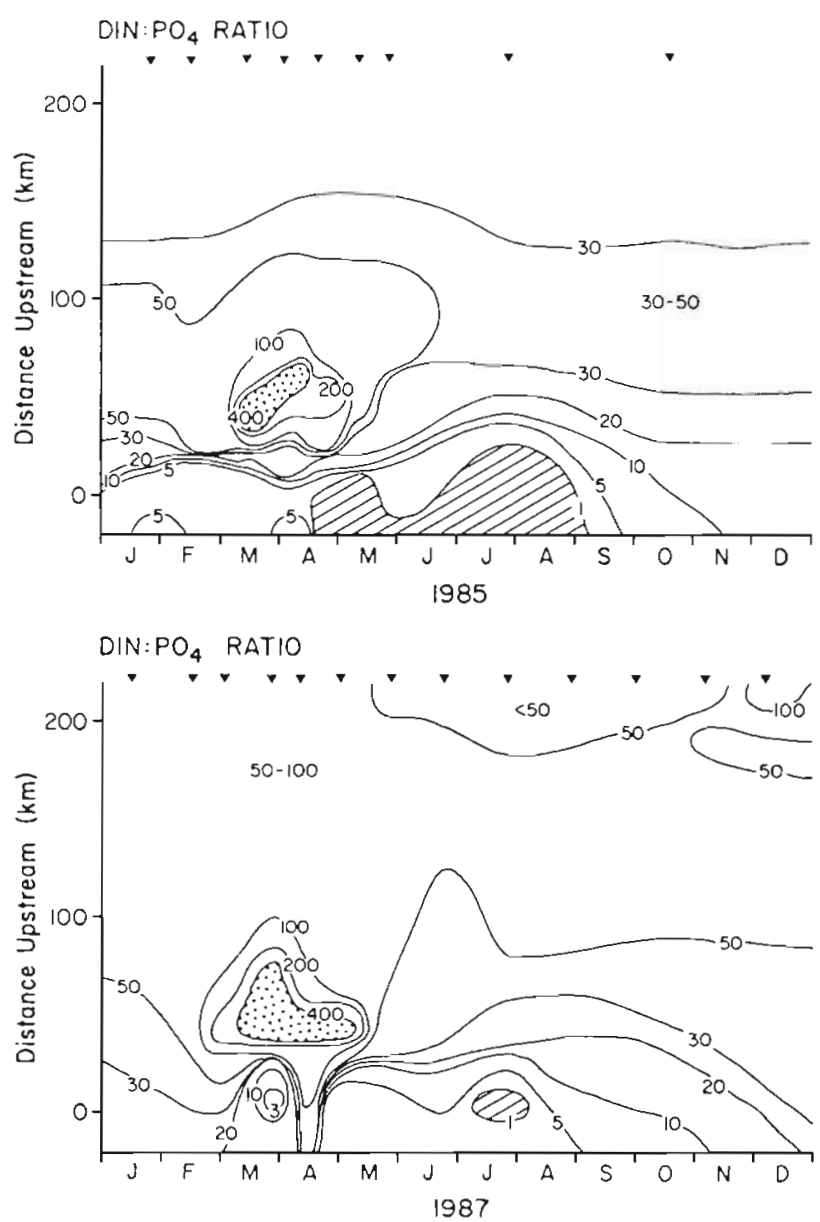

Fig. 6. Dissolved inorganic nitrogen to phosphate ratios (DIN: $\mathrm{PO}_{4}$ ) versus distance upstream for full seasonal cycles during 1985 and 1987. The stippled area delineates DIN: $\mathrm{PO}_{4}$ ratios $\geq 400$ while the hatched area represents ratios $\leq 1$ The distance axis runs from $0 \mathrm{~km}$ at the mouth of the estuary to $220 \mathrm{~km}$ at Trenton, NJ. Triangles along the upper $x$-axis indicate sampling times. Insufficient sampling was done upstream of $130 \mathrm{~km}$ in 1985 to compare the tidal river region in the 2 years

\section{$\mathrm{C}: \mathrm{N}: \mathrm{P}$ ratios}

DIN : $\mathrm{PO}_{4}$ ratios displayed marked variations over the seasonal cycles (Fig. 6). In the river, DIN: $\mathrm{PO}_{4}$ ratios of 20 to 50 were observed in 1985 while higher ratios (50 to 100) were found in 1987 primarily as a result of decreased $\mathrm{PO}_{4}$ concentrations. In the estuary, DIN: $\mathrm{PO}_{4}$ ratios increased to greater than 400 during the spring bloom in mid-estuary. In contrast, ratios below 5 were observed near the mouth of the bay throughout the late spring and summer period.

In 1987 (the year for which we have a complete PC:PN:PP data set), we examined atomic PC:PN and PN:PP particulate ratios as indicators of possible nitrogen and phosphorus limitation, respectively (Yentsch et al. 1977, Healey 1978, Nixon 1981, Hecky \& Kilham 1988 ). During this period, the PC:PN ratio in the estuary varied around an average value of 6.5:1 (range $2.5: 1$ to $13: 1 ; n=275$ ) but displayed no distinct patterns that could provide evidence of $\mathrm{N}$ - or P-limited growth either spatially or temporally (Fig. 7). In contrast, the PN:PP ratio varied between 1 and 11:1 $(n=275)$ and displayed a systematic elevation in the lower estuary during spring (Fig. 8) corresponding to the period of $\mathrm{PO}_{4}$ depletion. It was only in this spring period that the N:P ratio approached the Redfield Ratio (Redfield

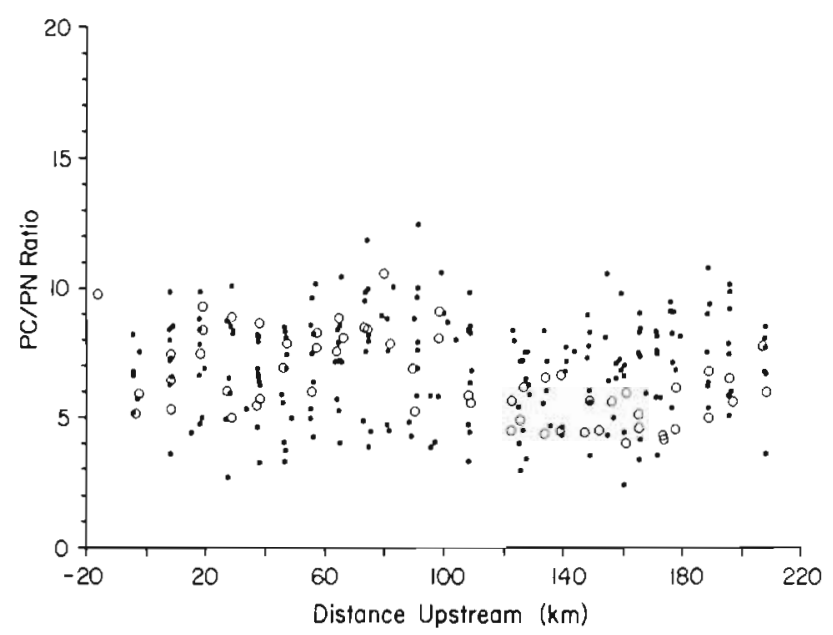

Fig. 7. Particulate carbon: nitrogen (PC:PN) ratios versus distance upstream in 1987 The distance axis runs from $0 \mathrm{~km}$ at the mouth of the estuary to $220 \mathrm{~km}$ at Trenton, NJ. Samples for the summer (June to September) period are identified by open circles

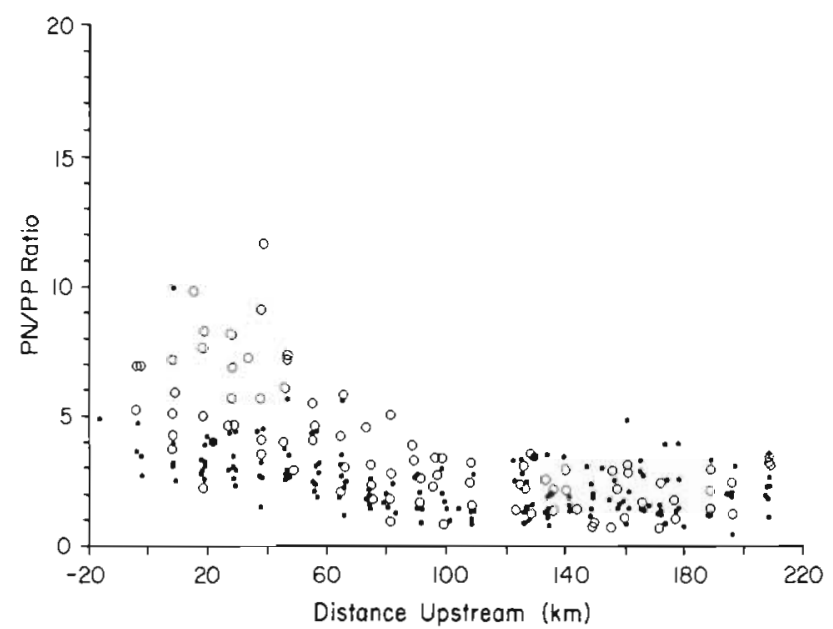

Fig. 8. Particulate nitrogen: phosphorus (PN:PP) ratios versus distance upstream in 1987. The distance axis runs from $0 \mathrm{~km}$ at the mouth of the estuary to $220 \mathrm{~km}$ at Trenton, NJ. Samples for the spring (March to May) period are identified by open circles 

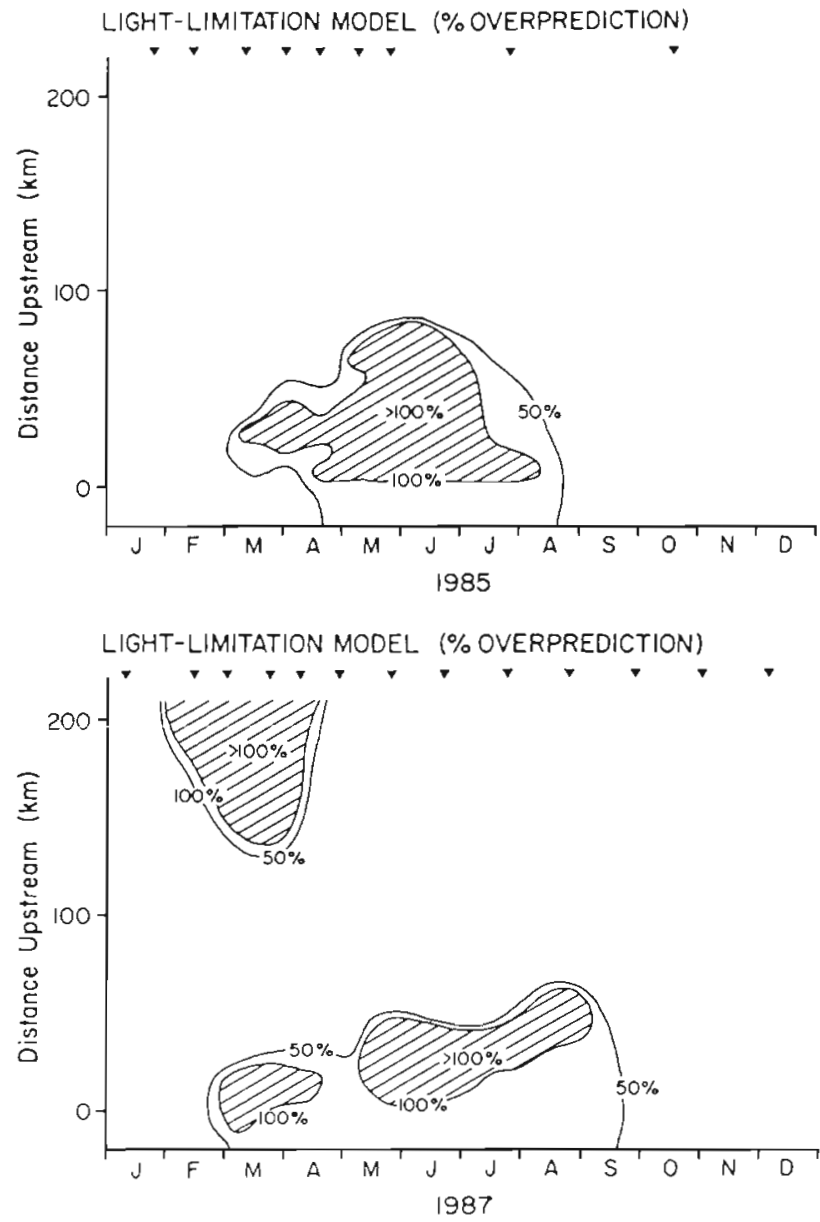

Fig. 9. Results of light-limitation modeling (presented as percent overprediction of observed chlorophyll) versus distance upstream for 1985 and 1987. Contours are presented for model results which overpredict observed chlorophyll concentrations by $50 \%$ and $100 \%$ et al. 1963) indicating significant P-enrichment in particulate matter (Lebo \& Sharp 1992) for most of the year.

\section{Light-limitation modeling}

Results from the light-limitation model revealed 2 periods when the model significantly overpredicted observed chlorophyll concentrations, indicating potential light limitation (Fig. 9). The first period occurred in the fresh tidal river during early spring 1987 (river data were not collected in spring 1985), during which both chlorophyll concentration and phytoplankton production were low. The second period occurred between March and late summer, beginning in mid-estuary in the region of the spring bloom and extending throughout the mid-and lower estuary during the summer period. These periods are thought to be periods when factors other than light were regulating phytoplankton production.

\section{Nutrient-enrichment experiments}

Nutrient-enrichment experiments carried out at the mid-bay station (CL) indicated that $\mathrm{PO}_{4}$ additions stimulated production between March and June, while $N$ additions simulated production during August (Fig. 10). During March and early April, $\mathrm{PO}_{4}$ appeared to be stoichiometrically deplete (SD), while we classified $\mathrm{P}$ as nutrient-limiting (NL) during late April and possibly June, while $N$ was nutrient-limiting in August. Results at the bay mouth station (BR) show that nitrogen additions stimulated production between late April and early May, and in October, while both
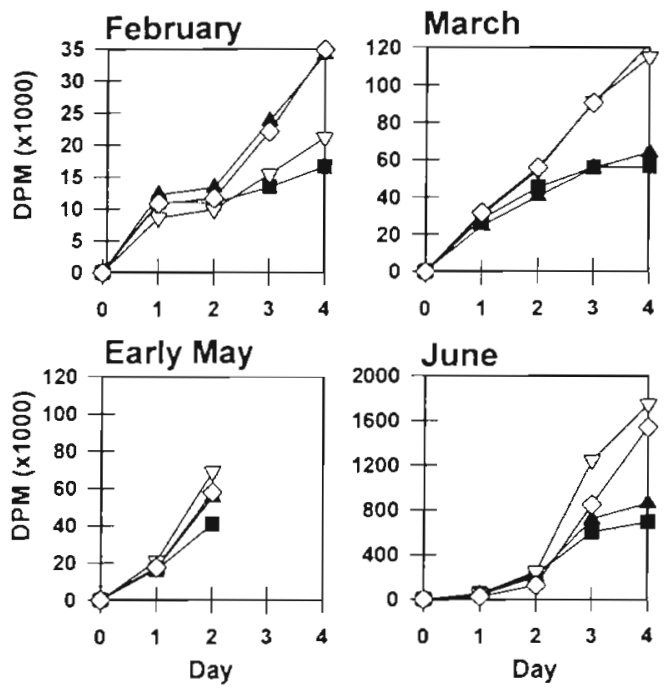

Early April

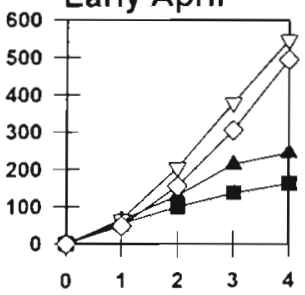

August

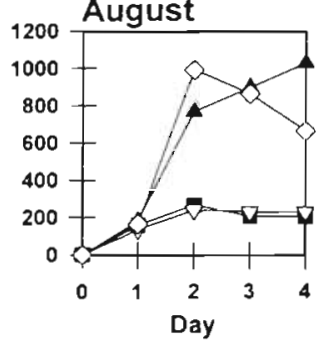

Late April

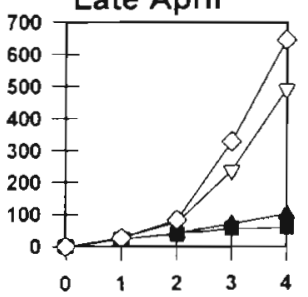

October

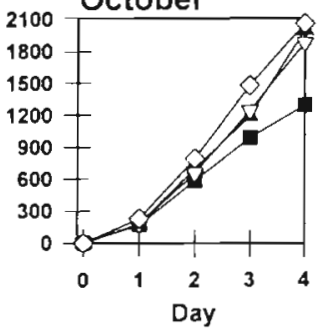

Fig. 10. Results of phytoplankton nutrient enrichment experiments performed in 1985 at Stn $\mathrm{CL}$ in the mid-estuary (see Fig. 1 for locations). (घ) Unenriched control; (A) nitrogen enriched; $(\nabla)$ phosphorus enrichedi $_{i}(\diamond)$ nitrogen and phosphorus enriched 
Fig. 11. Results of phytoplankton nutrient enrichment experiments performed in 1985 at Stn $\mathrm{BR}$ in the lower estuary (see Fig. 1 for locations). (a) Unenriched control; (A) nitrogen enriched; $(\nabla)$ phosphorus enriched; $(\diamond)$ nitrogen and phosphorus enriched
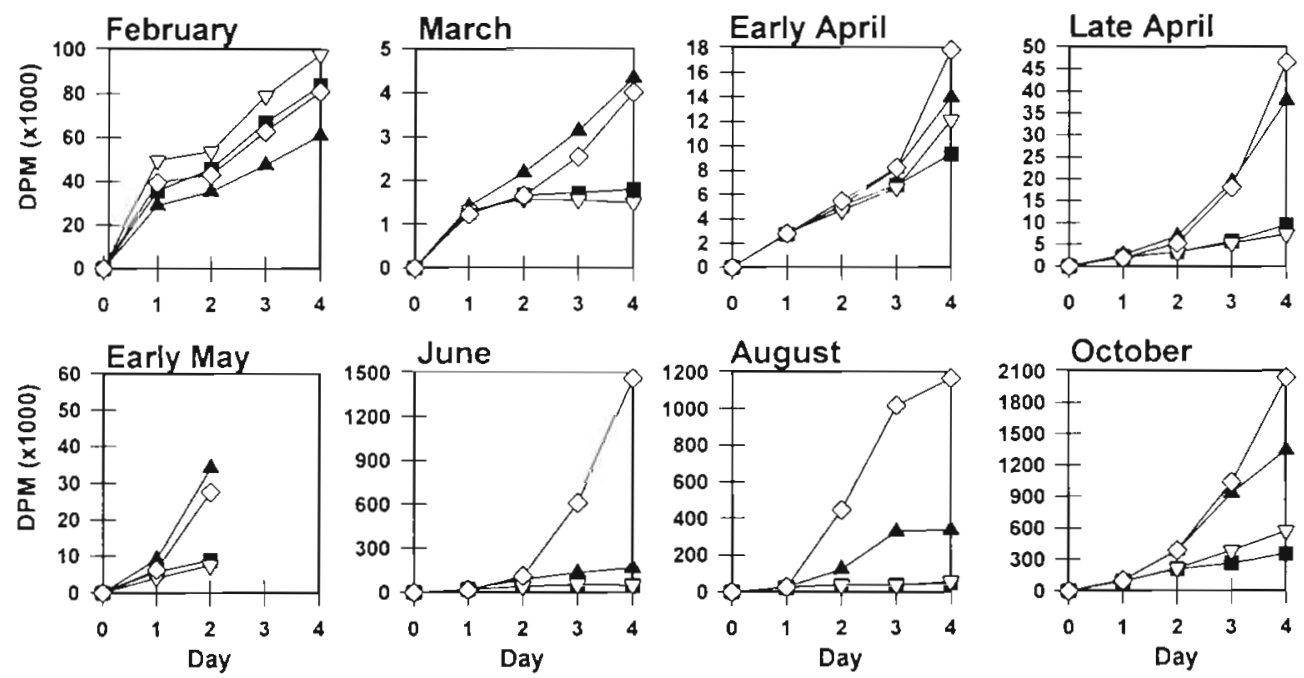

$\mathrm{N}$ and $\mathrm{P}$ influenced growth during June and August (Fig. 11). For these data, $\mathrm{N}$ appeared to be stoichiometrically deplete in March, while either $\mathrm{N}$ or $\mathrm{N}$ and $\mathrm{P}$ together were nutrient-limiting between late April and October.

\section{DISCUSSION}

\section{Temporal variations in phytoplankton growth limitation}

These observations of temporal variation in the factors that regulate phytoplankton production expand upon previous research in both freshwater and estuarine environments. For example, Lin \& Schelske (1981) found a seasonal variation in potential nutrientlimitation in Lake Huron (N. America) involving the primary limiting nutrient $P$ and several secondary limiting nutrients (EDTA, Fe and vitamins). Likewise, alternating periods of $\mathrm{P}$-, $\mathrm{N}$ - and light-limitation were observed in a eutrophic lake (Zevenboom et al. 1982), while $\mathrm{N}$ and $\mathrm{P}$ are often found to be co-limiting in more oligotrophic lake environments (Suttle \& Harrison 1988, Elser et al. 1990). In the estuarine environment, Smayda (1974) found that the growth of Thalassiosira pseudonana in bioassay experiments conducted in Narragansett Bay (USA) was limited primarily by $N$, but that organic chelators also limited growth at certain times. Seasonal transition between $\mathrm{P}$ - and $\mathrm{N}$ limitation was also observed in mesocosm studies from the Patuxent River Estuary, Maryland (D'Elia et al. 1986) and the Neuse River Estuary, North Carolina (Rudek et al. 1991). In these environments, limitation of phytoplankton growth-potential was related to variations in N:P stoichiometry associated with riverine inputs (D'Elia et al. 1986) and temperature-dependent biological processes (Pomeroy et al. 1972, Pilson et al.
1980, Elser et al. 1988). In a field study in Chesapeake Bay (USA), Fisher et al. (1992) found temporal variations in $\mathrm{N}$ - and P-limitation that they related primarily to the stoichiometry of nutrient inputs. The results from our research expand upon these earlier studies, by documenting a recurring pattern of estuarine phytoplankton growth and abundance that is alternately regulated by light, phosphorus and nitrogen as discussed below (Table 1).

\section{Light-limitation}

Although elevated turbidity in the brackish-water zone of many larger estuarine systems is an important regulator of phytoplankton production, no specific indicator of light-limitation is available experimentally. Physiological indices such as low-light adaptation that are useful in stable water masses (Falkowski \& Owens 1980, Harding et al. 1983) are less useful in well-mixed water columns where phytoplankton are frequently exposed to short periods of high light intensity during rapid vertical mixing (Harding et al. 1986, 1987, Pennock \& Sharp 1986). An alternative approach, in which light-limitation is ascertained through modeling chlorophyll biomass as a function of available light energy, has proven a successful indicator of lightlimitation in the Potomac (Wofsy 1983), Delaware (Pennock 1985) and Chesapeake Estuaries (Harding et al. 1986).

Light-limitation modeling produced results that were similar to those found previously in the Delaware (Pennock 1985). Light-limitation occurred throughout the year in the upper estuary (90 to $150 \mathrm{~km}$; Fig. 9) and in the lower estuary between mid-September and midFebruary. However, from early March until September, model results suggest that phytoplankton were 
Table 1 Conceptual summary of the factors that potentially Limit phytoplankton in 2 regions of the Delaware Estuary based on data from each of the hierarchical levels examined during this study. Potential limitation was assessed as follows: light, based on a $>50 \%$ overprediction of the light-limitation model $l_{i}$ nitrogen, based on DIN concentrations below $1 \mu \mathrm{M}$, DIN:PO $\mathrm{H}_{4} \mathrm{ratios}<8: 1$, $\mathrm{PC}: \mathrm{PN}$ ratios elevated above the annual average and bioassay results in which nitrogen additions stimulated production; and phosphorus, based on $\mathrm{PO}_{4}$ concentrations below $0.1 \mu \mathrm{M}$, DIN:PO $\mathrm{P}_{4}$ ratios $>32: 1$. PN.PP ratios elevated above the annual average and bioassay results in which phosphorus additions stimulated production). (-) indicates that a particular indicator did not meet the above criteria, and an asterisk ( ${ }^{\circ}$ ) indicates $\mathrm{DIN}: \mathrm{PO}_{4}$ ratios $>100$ for $\mathrm{P}$-limitation or $<1$ for $\mathrm{N}$-limitation

\begin{tabular}{|c|c|c|c|c|c|c|c|c|}
\hline Month & [DIN] & {$\left[\mathrm{PO}_{4}\right]$} & $\mathrm{DIN}: \mathrm{PO}_{4}$ & PC:PN & $P N: P P$ & Light model & Bioassay & Summary \\
\hline \multicolumn{9}{|c|}{ Mid-estuary $(\sim 40 \mathrm{~km})$} \\
\hline Jan-Feb & - & - & $\mathrm{P}$ & - & - & Light & - & Light \\
\hline Mar-Apr & - & $\mathrm{P}$ & $P^{\cdot}$ & - & $\mathrm{P}$ & Light & $\mathrm{P}$ & Light/P \\
\hline May-Jun & - & $\mathrm{P}$ & $\mathrm{P}$ & - & $\mathrm{P}$ & - & $\mathrm{P}$ & $\mathrm{P}$ \\
\hline Jul-Aug & - & - & $\mathrm{P}$ & - & - & - & $N$ & $\mathrm{~N} ?$ \\
\hline Sep-Oct & - & - & $\mathrm{P}$ & - & - & Light & - & Light \\
\hline Nov-Dec & - & - & $\mathrm{P}$ & - & - & Light & - & Light \\
\hline \multicolumn{9}{|c|}{ Lower estuary $(\sim 5 \mathrm{~km})$} \\
\hline Jan-Feb & - & - & $N$ & - & - & Light & - & Light \\
\hline Mar-Apr & $N$ & $\mathrm{P}$ & $N$ & - & - & - & N & $\mathrm{N}$ \\
\hline May-Jun & $N$ & $P$ & $N^{*}$ & - & - & - & $N \& P$ & $N \& P$ \\
\hline Jul-Aug & $N$ & - & $\mathrm{N}^{\bullet}$ & - & - & - & $N \& P$ & $N ?$ \\
\hline Sep-Oct & $\mathrm{N}$ & - & $\mathrm{N}$ & - & - & Light & $N$ & $N ?$ \\
\hline Nov-Dec & - & - & $N$ & - & - & Light & Light & Light \\
\hline
\end{tabular}

not light-limited in the mid-and lower estuary. This period, during which model results significantly overpredict observed chlorophyll values, begins as the spring diatom bloom migrates from the lower estuary towards the turbidity maximum (Fig. 2), and continues through the summer. Pennock (1985) has shown that the spring bloom is physically regulated by flow-induced stratification that decreases the depth of the surface mixed layer. The increased temporal and spatial sampling densities in 1985 and 1987 confirm this observation and further suggest that the dissipation of the bloom is caused by factors other than light.

\section{Phosphate-limitation}

Coinciding with the dissipation of the spring bloom and the overprediction of the light-limitation model, several indices suggest the occurrence of P-limitation in mid-estuary from mid-March through April. At this time, DIN: $\mathrm{PO}_{4}$ ratios exceed 400 (Fig. 6) as a result of significant loss of $\mathrm{PO}_{4}$ in the mid-and lower estuary (Fig. 5). At their minimum, these $\mathrm{PO}_{4}$ concentrations $(<0.1 \mu \mathrm{M})$ fall within the range for half-saturation constants for $\mathrm{PO}_{4}$ uptake (Nalewajko \& Lean 1980. Smith $\&$ Kalff 1982) suggesting the possibility of P-limitation. Bioassay experiments also support the occurrence of $P$. limitation in the mid-estuarine region (Fig 10) where DIN : $\mathrm{PO}_{4}$ ratios attained a maximum (Fig. 6). In addition, the observations of PN:PP in the estuary over the annual cycle revealed elevated ratios in the mid-and lower estuary during spring (Fig. 8). The low PN:PP average in the upper estuary has been shown to result from $\mathrm{PO}_{4}$ adsorption to inorganic particulates and phosphorus-rich mineral phases (Biggs et al. 1983, Lebo \& Sharp 1992). In light of this low PN: PP ratio, the elevated PN:PP ratios observed during spring support the interpretation of P-limitation. Such patterns have been observed previously in bioassay experiments (Maestrini et al. 1984, Schelske 1984), and in particulate (plankton) composition ratios (Antia et al. 1963, Healy \& Hendzel 1980), where they have been interpreted as indicators of P-limitation.

Thus, each of the available lines of evidence suggests P-limitation occurs in the mid-estuary during spring. Although there is a general notion that estuarine and marine systems are N-limited (Boynton et al. 1982), this study and several others provide evidence of P-limitation in estuarine ecosystems. For example, in the U.S., potential P-limitation based on DIN: $\mathrm{PO}_{4}$ ratios has been suggested for Albemarle Sound (Bowden \& Hobbie 1977), the Potomac River Estuary (Jaworski 1981), Apalachicola Bay and Chesapeake Bay (Fisher et al. 1992). Evidence for potential Plimitation using bioassay experiments has also been shown for several estuaries in the northeastern Gulf of Mexico (Meyers \& Iverson 1981), the Peel-Harvey Estuary, Australia (McComb et al. 1981), the Patuxent River Estuary (D'Elia et al. 1986), and Chesapeake Bay (Fisher et al. 1992).

Conceptually, it is possible to separate estuarine $\mathrm{P}$ limitation into 2 categories based on nutrient concentrations. In relatively unenriched estuaries with slightly elevated N:P ratios, such as Apalachicola Bay 
and the Econfina Estuary (Meyers \& Iverson 1981), P-limitation was suggested throughout much of the summer growth period. In more eutrophic systems with significantly elevated $\mathrm{DIN}: \mathrm{PO}_{4}$ input ratios (>30:1) such as the Delaware, Patuxent (D'Elia et al. 1986) and Chesapeake (Fisher et al. 1992), P-limitation is observed only during active phytoplankton growth during the winter/spring period when water temperatures are low. Fisher et al. (1992) attribute this seasonality to changes in the input ratios of DIN and $\mathrm{PO}_{4}$. In the Delaware, seasonal changes in nutrient input ratios are not obvious, but rather P-limitation is associated with fixation of $\mathrm{PO}_{4}$ into phytoplankton biomass (PP) which accumulates to high concentrations during the spring period (Table 1). This period lasts only a relatively short time, between March and early May, after which $\mathrm{PO}_{4}$ concentrations begin to rebound as a result of regeneration (Lebo \& Sharp 1992).

\section{Nitrogen-limitation}

Subsequent to and downstream of the region of P-limitation, several indices suggest the occurrence of $\mathrm{N}$-limitation at the mouth of the estuary beginning in late April and extending until September in both 1985 and 1987. As with phosphorus, nutrient concentrations (DIN < $1 \mu \mathrm{M}$ : Fig. 4), and DIN: $\mathrm{PO}_{4}$ stoichiometry (DIN: $\mathrm{PO}_{4}<5$ : Fig. 6) were in a range suggestive of potential $\mathrm{N}$-limitation and below the typical halfsaturation constant for $\mathrm{N}$ uptake reported for several estuarine and near-coastal systems ( 1 to $2 \mu \mathrm{M}$ : Eppley et al. 1969, Maclsaac \& Dugdale 1969, Fisher et al. 1981). Similarly, bioassay experiments suggested $\mathrm{N}$ limited growth at the bay mouth sampling station between late April and August in 1985.

In contrast to these results, however, PC:PN ratios (Fig. 7) were not elevated as has been seen in culture (Droop 1974, Rhee 1978) and in the field (Sakshaug \& Olsen 1986) under $\mathrm{N}$-limited conditions. These data could be interpreted in several ways. First, it is possible that detrital carbon and nitrogen obscure altered $C: N$ ratios in the plankton during summer. However, using carbon:chlorophyll ratios $(30: 1)$ we can estimate that $>60 \%$ of the organic carbon in the lower estuary during 1987 was contributed by living phytoplankton. Alternatively, the PC:PN ratio may correctly reflect a situation in which phytoplankton are not severely $\mathrm{N}$-limited and rather that the other indices are misleading (Table 1).

We believe that this second explanation is most probable. Although DIN concentrations and DIN: $\mathrm{PO}_{4}$ ratios near the bay mouth support the possibility of $\mathrm{N}$-limitation, DIN concentrations in the upper Delaware River are among the highest in the world (Sharp 1988), and this material is continually advected through the brackish-water region and into the lower estuary (Sharp et al. 1984). As a result, we suggest that the lower estuary acts analogously to a chemostat during summer, with relatively high rates of phytoplankton production ( 0.5 to $2 \mathrm{~g} \mathrm{C} \mathrm{m}^{-2} \mathrm{~d}^{-1}$; Fig 3) being supported by both remineralized $\mathrm{N}$ and $\mathrm{N}$ advected from upstream, while biomass is limited by grazing. This hypothesis is supported by ${ }^{15} \mathrm{~N}$ uptake experiments which generally display nutrient-saturated uptake kinetics throughout the estuary (Pennock 1987), and high $P_{\mathrm{rn}}{ }^{\mathrm{B}}$ values suggesting robust phytoplankton growth (Pennock \& Sharp 1986).

If accurate, this explanation contradicts the interpretation of the bioassay experiments, suggesting that isolation of the natural phytoplankton populations from continuous nutrient supply and grazing pressure can lead to misidentification of nutrient-limitation. Further, in the absence of both light- and nutrient-limitation, this conclusion suggests that grazing is a major regulator of phytoplankton biomass in the lower estuary during summer.

\section{Factors regulating growth limitation}

The above scenario provides clear evidence of temporal variability in the factors that regulate estuarine phytoplankton growth. Ultimately, however, it is important to further identify the processes that regulate these factors. For example, although input ratios of $\mathrm{N}$ and $P$ impart an important influence on the regulation of estuarine phytoplankton production (Fisher et al. 1992), it is clear that variations in N:P stoichiometry along the estuarine gradient (Fig. 6) occur independent of input ratios (Fig. 12). Several factors, including physical flushing/mixing rates, geochemical equilibria reactions, and biological processes appear to be important regulators of nutrient availability and, ultimately, the temporal patterns of growth limitation that are observed.

In the Delaware Estuary, freshwater discharge plays an important role in determining both total nutrient loading and the N:P input ratio available to phytoplankton. However, this nutrient loading is significantly modified by biogeochemical processes within the estuary. For example, geochemically, the predominant reactions are ones that raise the DIN: $\mathrm{PO}_{4}$ input ratio to the estuary (Fig. 12) by removing $\mathrm{PO}_{4}$ from the dissolved phase during transit through the river. As a result, $\mathrm{DIN}: \mathrm{PO}_{4}$ ratios entering the brackish region, which ultimately fuel phytoplankton growth in the lower estuary, are stoichiometrically deplete in $\mathrm{P}$ $(\sim 100: 1)$, despite riverine $(30: 1)$ and point-source inputs (6:1) that are near or below typical phytoplankton requirements (Redfield et al. 1963). The net result is the occurrence of P-limitation during the late 


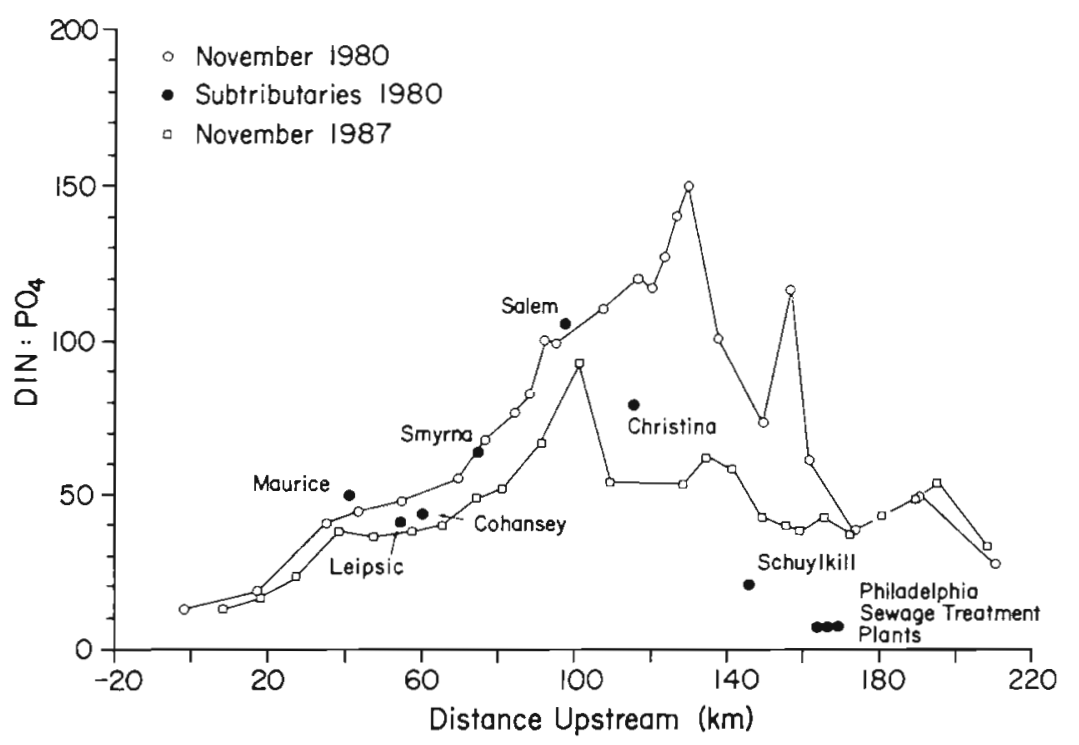

Fig. 12. Delaware Estuary: dissolved inorganic nitrogen to phosphate (DIN: $\mathrm{PO}_{4}$ ) ratios versus distance upstream during the falls of 1980 and 1987. During the fall period when phytoplankton activity is at a minimum, DIN: $\mathrm{PO}_{4}$ ratios display marked enrichment in the Philadelphia region just upstream of the salt line. These processes, which act counter to the influence of point-source sewage inputs in the region, serve to elevate DIN: $\mathrm{PO}_{4}$ input ratios by removing $\mathrm{PO}_{4}$ from the dissolved phase spring period, during which physical flushing and phytoplankton growth are the predominant processes within the system.

As the influence of freshwater discharge decreases towards summer, biogeochemical regeneration of $\mathrm{P}$ as a result of heterotrophic activity and inorganic desorption reactions significantly decreases the DIN: $P_{4}$ ratio in the estuary. The overall consequence is that $\mathrm{N}$ becomes stoichiometrically deplete in the lower estuary during the summer, as indicated by the DIN: $\mathrm{PO}_{4}$ ratios and nutrient enrichment experiments. In the Delaware, this does not appear to result in physiological N-limitation - that would be indicated by changes in the $C: N$ ratio of the particulate matter. However, in ecosystems in which light availability and riverine nutrient flux are not as dominant as they are in the Delaware, these biogeochemical processes will likely act to regulate $\mathrm{N}$ availability and ultimately result in $\mathrm{N}$-limited growth.

Acknowledgements. We thank J. Ludlam, M. Lebo, L. Cifuentes, and R. Coffin for analytical support. R. Gieder, M. Lebo and an anonymous reviewer provided insightful comments on earlier versions of this manuscript. This research was supported by the NSF (OCE 86-01616) and the NOAA Office of Sea Grant (NA 83AA-D-0017, NA 85AA-D-SG033 and NA 86AA-D-SG040) through the Delaware Sea Grant College Program. Marine Environmental Sciences Consortium Contribution \#254.

\section{LITERATURE CITED}

Albert, R. C., Krausch, R. C. (1988). A river reach profile of mid-1980s water quality of the Delaware River. In: Majumdar, S. K., Miller, E. W., Sage, L. E. (eds.) Ecology and restoration of the Delaware River basin. The Pennsylvania Academy of Science, Philadelphia, p. 39-57
Antia, N. J., McCallister, C. D., Parsons, T R., Stephens, K. Strickland, J. D. H. (1963). Further measurements of primary production using a large-volume plastic sphere. Limnol. Oceanogr. 8: 166-183

Biggs, R. B., Sharp, J. H., Church, T. M., Tramontano, J. M. (1983). Optical properties, suspended sediments, and chemistry associated with the turbidity maxima of the Delaware Estuary. Can. J. Fish. Aquat. Sci. 40: 172-179

Bowden, W. B., Hobbie, J. E. (1977). Nutrients in Albemarle Sound, North Carolina. University of North Carolina Sea Grant College Publication, UNC-SG-75-25, Raleigh

Boynton, W. R., Kemp, W. M., Keefe, C. W. (1982). A comparative analysis of nutrients and other factors influencing estuarine phytoplankton production. In: Kennedy, V. (ed.) Estuarine comparisons. Academic, San Diego, p. 69-90

Broecker, W. S., Peng, T.-H. (1982). Tracers in the sea. Lamont-Doherty Geological Observatory, New York

Butler, E. I, Tibbets, S. (1972). Chemical survey of the Tamar Estuary. I. Properties of the waters. J. mar. biol. Ass. U.K. 52: $681-699$

Cifuentes, L. A. (1991). Spatial and temporal variations in terrestrially-derived organic matter from sediments of the Delaware Estuary. Estuaries 14:414-429

Cifuentes, L. A., Sharp, J. H., Fogel, M. L. (1988). Stable carbon and nitrogen isotope biogeochemistry in the Delaware Estuary. Limnol. Oceanogr. 33: 1102-1115

Coffin, R. B., Sharp, J. H. (1987). Microbial trophodynamics in the Delaware Estuary. Mar. Ecol. Prog. Ser. 41: 253-261

Copin-Montegut, C., Copin-Montegut, G. (1983). Stoichiometry of carbon, nitrogen, and phosphorus in marine particulate matter. Deep Sea Res. 30: 31-46

D'Elia, C. F., Nelson, D. M., Boynton, W. R. (1983). Chesapeake Bay nutrient and plankton dynamics: III. The annual cycle of dissolved silicon. Geochim. Cosmochim. Acta 47: 1945-1955

D'Elia, C. F., Sanders, J. G., Boynton, W. R. (1986). Nutrient enrichment studies in a coastal plain estuary: phytoplankton growth in large-scale, continuous cultures. Can. J. Fish. Aquat. Sci. 43: 397-406

Dortch, Q., Whitledge, T E. (1992). Does nitrogen or silicon limit phytoplankton production in the Mississippi River plume and nearby regions? Cont. Shelf Res. 12: $1293-1.309$ 
Droop, M. R. (1974). The nutrient status of algal cells in continuous culture. J. mar. biol. Ass. U.K. 54: 825-855

Droop, M. R. (1977). An approach to quantitative nutrition of the phytoplankton. J. Protozool. 24: 528-531

Elser, J. J., Elser, M. M., Mackay, N. A., Carpenter, S. R. (1988). Zooplankton-mediated transitions between $\mathrm{N}$ - and P-limited algal growth. Limnol. Oceanogr. 33: 1-14

Elser, J. J., Marzolf, E. R., Goldman, C. R. (1990). Phosphorus and nitrogen limitation of phytoplankton growth in the freshwaters of North America: a review and critique of experimental enrichments. Can. J. Fish. Aquat. Sci. 47 $1468-1477$

Eppley, R. W., Holmes, R. W., Strickland, J. D. H. (1967). Sinking rates of marine phytoplankton measured with a fluorometer. J. exp. mar. Biol. Ecol. 1: 191-208

Eppley, R. W., Rogers, J. N., McCarthy, J J. (1969). Halfsaturation constants for uptake of nitrate and ammonium by marine phytoplankton. Limnol. Oceanogr. 14: 912-920

Eppley, R. W., Sharp, J. H. (1975). Photosynthetic measurements in the central north Pacific: the dark loss of carbon in 24-h incubations. Limnol. Oceanogr. 20: 981-987

Falkowski, P. G., Owens, T. G. (1980). Light-shade adaptation. Two strategies in marine phytoplankton. Pl. Physiol. 66: 592-595

Fisher, T R., Carlson, P. R., Barber, R. T. (1981). Some problems in the interpretation of ammonium uptake kinetics Mar. Biol. 2: 33-44

Fisher, T. R., Peele, E. R., Ammerman, J. W., Harding, L. W. (1992). Nutrient limitation of phytoplankton in Chesapeake Bay, Mar. Ecol. Prog. Ser. 82: 51-63

Goldman, J. C. (1976). Identification of nitrogen as a growthlimiting nutrient in wastewaters and coastal marine waters through continuous culture algal assays. Water Res. 10: 97-104

Goldman, J. C., McCarthy, J. J., Peavey, D. G. (1979). Growth rate influence on the chemical composition of phytoplankton in oceanic waters. Nature 279: 210-215

Harding, L. W. Jr, Fisher, T R. Jr, Tyler, M. A. (1987) Adaptive responses of photosynthesis in phytoplankton: specificity to time-scale of change in light. Biol. Oceanogr. 4: $419-453$

Harding, L. W. Jr, Meeson, B. W., Fisher, T R. Jr (1986). Phytoplankton production in two east coast estuaries photosynthesis-light functions and patterns of carbon assimilation in Chesapeake and Delaware Bays. Estuar. coast. Shelf Sci. 23: 773-806

Harding, L. W. Jr, Meeson, B. W., Tyler, M. A. (1983). Photoadaptation and diel periodicity of photosynthesis in the dinoflagellate Prorocentrum mariae-lebouriae. Mar. Ecol. Prog. Ser. 13: 73-85

Harris, G. P. (1986). Phytoplankton ecology: structure, function and fluctuation. University Press, Cambridge

Harrison, P. J., Hu, M. H., Yang, Y. P., Lu, X. (1990). Phosphate limitation in estuarine and coastal waters of China. J. exp. mar. Biol. Ecol. 140: 79-87

Healey, F. P. (1978). Physiological indicators of nutrient deficiency in algae. Mitt. int. Ver. theor. angew. Limnol. 21: $34-41$

Healey, F. P., Hendzel, L. L. (1980). Physiological indicators of nutrient deficiency in lake phytoplankton. Can. J. Fish. Aquat. Sci. 37: 442-453

Hecky, R. E., Kilham, P. (1988). Nutrient limitation of phytoplankton in freshwater and marine environments: a review of recent evidence on the effects of enrichment. Limnol. Oceanogr. 33: 796-822

Jaworski, N. A. (1981). Sources of nutrients and the scale of eutrophication problems in estuaries. In: Neilson, B. J., Cronin, L. E. (eds.) Estuaries and nutrients. Humana, Clifton, NJ, p. 83-110

Lebo, M. E. (1990). Phosphate uptake along a coastal plain estuary. Limnol. Oceanogr. 35(6): 1279-1289

Lebo, M. E., Sharp, J. H. (1992). Modeling phosphorus cycling in a well mixed coastal plain estuary. Estuar coast. Shelf Sci. 35: 235-252

Liebig, J. (1855). Die Grundsätze der Agricultur-Chemie mit Rücksicht auf die in England angestellten Untersuchungen. F. Vieweg und Sohn, Braunschweig. [English translation published in Principles of Agricultural Chemistry by Wiley, Somerset]

Lin, C. K., Schelske, C. L. (1981). Seasonal variation of potential nutrient limitation to chlorophyll production in southern Lake Huron. Can. J. Fish. Aquat. Sci. 38: 1-9

Lorenzen, C. J. (1967). Determination of chlorophyll and phaeo-pigments: spectrophotometric equations. Limnol. Oceanogr. 12: 343-346

MacIsaac, J. J., Dugdale, R. C. (1969). The kinetics of nitrate and ammonium uptake by natural populations of marine phytoplankton. Deep Sea Res. 16: 45-57

Maestrini, S. Y., Bonin, D. J., Droop, M. R. (1984). Phytoplankton as indicators of sea water quality: bioassay approach and protocols. In: Shubert, L. E. (ed.) Algae as ecological indicators. Academic, San Diego, p. 71-132

McComb, A. J., Atkins, R. P., Birch, P. B., Gordon, D. M. Lukatelich, R. J. (1981). Eutrophication in the Pell-Harvey Estuarine System, Western Australia. In: Neilson, B. J., Cronin, L. E. (eds.) Estuaries and nutrients. Humana, Clifton, NJ, p. 323-342

Meyers, V. B., Iverson, R. I. (1981). Phosphorus and nitrogen limited phytoplankton productivity in northeastern Gulf of Mexico coastal estuaries. In: Neilson, B. J., Cronin, L. E. (eds.) Estuaries and nutrients. Humana, Clifton, NJ p. $569-582$

Nalewajko, C., Lean, D. R. S. (1980). Phosphorus. In: Morris, I. (ed.) Physiological ecology of phytoplankton. Blackwell Scientific, Cambridge, p. 235-258

Nixon, S. W. (1981). Remineralization and nutrient cycling in coastal marine ecosystems. In: Neilson, B. J., Cronin, L. E. (eds.) Estuaries and nutrients. Humana, Clifton, NJ, p. 111-138

Nixon, S. W., Pilson, M. E. Q. (1983). Nitrogen in estuarine and coastal marine ecosystems. In: Carpenter, E. J., Capone, D. G. (eds.) Nitrogen in the marine environment. Academic, San Diego, p. 565-648

Nixon, S. W., Pilson, M. E. Q. (1984). Estuarine total system metabolism and organic exchange calculated from nutrient ratios: an example from Narragansett Bay. In: Kennedy, V. S. (ed.) The estuary as a filter. Academic, San Diego, p. 261-290

Nixon, S. W., Pilson, M. E. Q., Oviatt, C. A., Donaghay, P., Sullivan, B., Seitzinger, S., Rudnick, D., Frithsen, J. (1984). Eutrophication of a coastal marine ecosystem - an experimental study using the MERL microcosms. In: Fasham, M. J. R. (ed.) Flows of energy and materials in marine ecosystem. Plenum, New York, p. 105-135

Pennock, J. R. (1985). Chlorophyll distributions in the Delaware Estuary: regulation by light-limitation. Estuar. coast. Shelf Sci. 21: 711-725

Pennock, J. R. (1987). Temporal and spatial variability in phytoplankton ammonium and nitrate uptake in the Delaware Estuary. Estuar. coast. Shelf Sci. 24: 841-857

Pennock, J. R., Sharp, J. H. (1986). Phytoplankton production in the Delaware Estuary: temporal and spatial variability. Mar. Ecol. Prog. Ser. 34: 143-155 
Pilson, M. E. Q., Oviatt, C. A., Nixon, S. W (1980). Annual nutrient cycles in a marine microcosm. In: Giesy, J. P. (ed.) Microcosms in ecological research. DOE Symposium Series, Augusta, Georgia, Nov. 8-10, 1978. CONF 781101 NTIS, Springfield, VA, p. 753-778

Pomeroy, L. R., Shenton, L. R., Jones, R. D. H., Reimold, R. J. (1972). Nutrient flux in estuaries. In: Likens, G. E. (ed.) Nutrients and eutrophication. Am. Soc. Limnol Oceanogr. Spec. Symp., Vol. 1, Lawrence, Kansas, p. 274-291

Redfield, A. C., Ketchum, B. H., Richards, F. A. (1963). The influence of organisms on the composition of seawater. In: Hill, M. N. (ed.) The sea. Interscience, New York, p. 26-77

Rhee, G. Y. (1978). Effects of N:P atomic ratios and nitrate limitation on algal growth, cell composition, and nitrate uptake. Limnol. Oceanogr. 23: 10-24

Rudek, J., Paerl, H. W., Mallin, M. A., Bates, P. W. (1991). Seasonal and hydrological control of phytoplankton nutrient in the lower Neuse River estuary, North Carolina. Mar. Ecol. Prog. Ser. 75: 133-142

Ryther, J. H., Dunstan, W. M. (1971). Nitrogen, phosphorus, and eutrophication in the coastal marine environment. Science 171: 1008-1013

Sakshaug, E. (1977). Limiting nutrients and maximum growth rates for diatoms in Narragansett Bay. J. exp. mar. Biol. Ecol. 28: 109-123

Sakshaug, E., Olsen, Y (1986). Nutrient status of phytoplankton blooms in Norwegian waters and an algal strategy for nutrient competition. Can. J. Fish. Aquat. Sci. 43: 389-396

Schelske, C. L. (1984). In situ and natural phytoplankton assemblages bioassays. In: Shubert, L. E. (ed.) Algae as ecological indicators. Academic, San Diego, p. 15-47

Schindler, D. W. (1975). Whole-lake eutrophication experiments with phosphorus, nitrogen, and carbon. Verh. int. Verein. Limnol. 19: 3221-3231

Schindler, D. W. (1977). Evolution of phosphorus limitation in lakes. Science 195: 260-262

Schindler, D. W. (1985). The coupling of elemental cycles by organisms: evidence from whole-lake chemical perturbation. In: Stuum, W. (ed.) Chemical processes in lakes. Wiley, Somerset, p. 225-250

Sharp, J. H. (1974). Improved analysis for particulate organic carbon and nitrogen from seawater. Limnol. Oceanogr 19: $984-989$

Sharp, J. H. (1988). Trends in nutrient concentrations in the Delaware Estuary. In: Majumdar, S. K., Miller, E. W., Sage, L. E. (eds.) Ecology and restoration of the Delaware River basin. The Pennsylvania Academy of Science, Philadelphia, p. 78-92

Sharp, J. H., Church, T M. (1980). Biochemical modeling in coastal waters of the middle Atlantic states. Limnol. Oceanogr. 26: 843-854

Sharp, J. H., Cifuentes, L. A., Coffin, R. B., Pennock, J. R., Wong, K.C. (1986). The influence of river variability on the circulation, chemistry, and microbiology of the Delaware estuary. Estuaries 9: 261-269

Sharp, J. H., Culberson, C. A., Church, T M. (1982). The chemistry of the Delaware Estuary: general considerations. Limnol. Oceanogr. 27: 1015

Sharp, J. H., Pennock, J. R., Church, T. M., Tramontano, J. M., Cifuentes, L. A. (1984). The estuarine interaction of nutrients, organics, and metals: a case study in the Delaware Estuary. In: Kennedy, V. S. (ed.) The estuary as a filter. Academic, San Diego, p. 241-258

Smayda, T. J. (1974). Bioassay of the growth potential of the surface water of lower Narragansett Bay over an annual cycle using the diatom Thalassiosira pseudonana loceanic clone, 13-1). Limnol. Oceanogr. 19: 889-901

Smith, R. E. H., Kalff, J. (1982). Size-dependent phosphorus uptake kinetics and cell quota in phytoplankton. J. Phycol. 18: $275-284$

Smith, S. V. (1984). Phosphorus versus nitrogen limitation in the marine environment. Limnol. Oceanogr. 29: 1149-1160

Solorzano, L., Sharp, J. H. (1980). Determination of total dissolved phosphorus and particulate phosphorus in natural waters. Limnol. Oceanogr. 25: 754-758

Strickland, J. D. H., Parsons, T. R. (1972). A practical handbook of seawater analysis. Bull. Fish. Res. Bd Can. 167

Suttle, C. A., Harrison, P. J. (1988). Ammonium and phosphate uptake rates, N:P supply ratios, and evidence for $\mathrm{N}$ and P-limitation in some oligotrophic lakes. Limnol. Oceanogr. 33: 186-202

Vincent, W. F., Wurtbaugh, W., Vincent, C. L., Richerson, P. J. (1984). Seasonal dynamics in a tropical high-altitude lake (Lake Titicaca, Peru-Bolivia): application of physiological bioassays. Limnol Oceanogr. 29: 540-552

Vollenweider, R. A. (1976). Advances in defining critical loading levels of phosphorus in lake eutrophication. Mem. Ist. Ital. Idrobiol. 33: 53-83

Wofsy, S. (1983). A simple model to predict extinction coefficients and phytoplankton biomass in eutrophic waters. Limnol. Oceanogr. 28: 1144-1155

Yentsch, C. M., Yentsch, C. S., Strube, L. R. (1977). Variations in ammonium enhancement, an indication of nitrogen deficiency in New England coastal phytoplankton populations. J. mar. Res. 35: 537-555

Zevenboom, W., De Vaate, A. B., Mur, L. (1982). Assessment of factors limiting growth rate of Oscillatoria agarahii in hypertrophic Lake Wolderwijd, 1978, by the use of physiological indicators. Limnol. Oceanogr. 27: 39-52

Manuscript first received: September 13, 1993

Revised version accepted: April 21, 1994 